SALAM; Jurnal Sosial \& Budaya Syar-i

FSH UIN Syarif Hidayatullah Jakarta

Vol. 7 No. 12 (2020), pp. 1246-1166, DOI: 10.15408/sjsbs.v7i7.15407

\title{
Pencegahan Primer Membentuk Masyarakat Sehat Di Era Covid-19*
}

\author{
Nikma Fitriasari ${ }^{1}$ \\ Universitas Brawijaya Malang \\ do \\ $\underline{10.15408 / \text { sjsbs.v7i7.15407 }}$
}

\begin{abstract}
The situation of the growth of COVID-19 cases is very fast in Indonesia. Primary prevention efforts become the most appropriate prevention because there is no drug for COVID-19 therapy. This research aims to further study the proper and rational primary prevention to establish a healthy society as an effort to prevent transmission of COVID-19. Primary prevention can be done in the form of health promotion and special protection. Primary prevention through promotion is done by selectively selecting information from social media, applying a cough ethic, consumption of nutritious food, and exercise. Primary prevention through special protection is done by resignation. cleaning hands regularly, using masks, social distancing and self-isolation, and avoiding unprotected contact with wild animals.
\end{abstract}

Keyword: COVID-19, primary prevention, healthy society

\begin{abstract}
Abstrak
Situasi pertumbuhan kasus COVID-19 sangat cepat di Indonesia. Upaya pencegahan primer menjadi pencegahan yang paling tepat karena belum ada obat untuk COVID-19. Penelitia ini bertujuan untuk mengkaji lebih jauh tentang pencegahan primer yang tepat dan rasional untuk membentuk masyarakat sehat sebagai upaya pencegahan penularan kasus COVID19. Pencegahan primer dapat dilakukan berupa promosi kesehatan dan perlindungan khusus. Pencegahan primer melalui promosi dilakukan dengan selektif memilih informasi dari media sosial, menerapkan etika batuk, konsumsi makanan bergizi, dan olahraga. Pencegahan primer melalui perlindungan khusus dilakukan dengan resignasi. membersihkan tangan secara rutin, menggunakan masker, social distancing dan isolasi diri, serta menghindari kontak tanpa pelindung dengan hewan liar.
\end{abstract}

Kata Kunci: COVID-19, pencegahan primer, masyarakat sehat

* Received: July 15, 2020, Revision: July 18, 2020, Published: December 5, 2020.

${ }^{1}$ Nikma Fitriasari adalah dosen pada Fakultas Kedokteran Universitas Brawijaya (Jalan Veteran, Malang, Jawa Timur, 65141, Indonesia). E-mail: nikmafitriasari@ub.ac.id 


\section{A. PENDAHULUAN}

Dunia dikejutkan dengan wabah Corona virus disease (COVID-19) di awal tahun 2020. WHO telah menetapkan dunia berada dalam darurat global. ${ }^{2}$ COVID-19 menimbulkan keresahan dunia karena penyebaran yang cepat dan menyebabkan kematian ${ }^{3}$. COVID-19 merupakan penyakit yang disebabkan oleh virus baru, yaitu virus korona novel (SARS-CoV-2). Virus ini dapat menular pada manusia dan menggangu sistem pernafasan, hingga menyebabkan kematian. Gejala dan tanda umum yang ditemukan pada orang terinfeksi virus korona adalah demam tinggi di atas $38^{\circ} \mathrm{C}$, batuk, dan sesak ${ }^{4}$. COVID-19 memiliki masa inkubasi sekitar 14 hari. COVID-19 memiliki virulensi atau kemampuan yang tinggi sehingga menyebabkan kerusakan paru-paru dan cairan lendir yang banyak. Cairan lendir ini yang menyebabkan sumbatan jalan nafas. Penyebaran virus melalui udara yang masuk melalui hidung dan mulut. Sampai saat ini, belum ada obat yang memiliki kemampuan membunuh virus.

COVID-19 ditemukan pertama kali di kota Wuhan Cina. Virus ini diduga ditularkan dari hewan kepada manusia. Virus ini menyebar sangat cepat hingga ke Indonesia. Kasus pertama COVID-19 di Indonesia ditemukan di Depok pada tanggal 1 Maret 2020. Dua pasien dari Depok tertular setelah berinteraksi dengan warga Jepang. ${ }^{5}$ Virus ini cepat menyebar ke seluruh nusantara dan tercatat kasus COVID-19 pada tanggal 16 April 2020 sebanyak 6.760 kasus. Jumlah kasus COVID-19 terdiri dari 5.423 kasus masih dalam perawatan, 590 kasus meninggal, dan 747 kasus dinyatakan sembuh. ${ }^{6}$

Hasil perhitungan Fajar (2020) menunjukkan pola pergerakan jumlah akumulatif individu terkonfirmasi positif COVID-19 meningkat secara eksponensial. Hal ini menunjukkan bahwa penularan COVID-19 sangat cepat. Jumlah kasus positif akan terus meningkat sampai pada titik dimana pergerakan jumlah kumulatif individu stabil. ${ }^{7}$

Melihat situasi pertumbuhan kasus COVID-19 yang cepat dan mematikan, upaya pencegahan harus dilakukan secara cepat dan tepat. Pencegahan dapat dilakukan melalui pencegahan primer, pencegahan sekunder dan pencegahan tersier. Pencegahan primer adalah tindakan yang diambil sebelum terjadi masalah kesehatan. Pencegahan primer dapat dilakukan dengan promosi kesehatan serta perlindungan diri. Pencegahan sekunder adalah tindakan yang diambil setelah terjadi masalah kesehatan. Pencegahan sekunder menekankan pada upaya penemuan masalah

2 Buana, Dana, Riksa, “Analisis Perilaku Masyarakat Indonesia dalam Menghadapi Pandemi Virus Corona (Covid-19) dan Kiat Menjaga Kesejahteraan Jiwa," Salam: Jurnal Sosial dan Budaya Syar-I 7, no. 3 (2020).

3 Telaumbanua, Dalinama, "Urgensi Pembentukan Aturan Terkait Pencegahan Covid-19 di Indonesia," Qalamuna: Jurnal Pendidikan, Sosial, dan Agama 12, no. 1 (2020): 59-70.

${ }^{4}$ Fajar, M, “Estimation of Cvid 19 Reproductive Number Case of Indonesia," (2020).

${ }^{5}$ Zulfa, tarisa, Novita, Indana, “Covid-19 dan Kecenderungan Psikosomatis,” (2020).

${ }^{6}$ Kompas.com, “Update 20 April: Sebaran 185 Kasus Baru Pasien Covid-19 Di 13 Provinsi," 2020, https://nasional.kompas.com.

${ }^{7}$ Fajar, M, “Estimation of Cvid 19 Reproductive Number Case of Indonesia,” (2020). 
kesehatan dan pengobatan sejak dini. Pencegahan tersier adalah tindakan yang diambil setelah masalah kesehatan teratasi dengan mencegah kekambuhan dan kecacatan. ${ }^{8}$ Mengingat belum ada obat untuk membunuh virus korona, maka pencegahan primer yang paling tepat untuk dilakukan.

Pencegahan primer sebagai salah satu cara membentuk masyarakat sehat. Masyarakat sehat adalah masyarakat yang memiliki pengetahuan untuk melalukan upaya pencegahan, peningkatan derajat kesehatan melalui usaha-usaha pengorganisasian masyarakat. Usaha-usaha pengorganisasian dapat dilakkan dengan perbaikan sanitasi ligkungan, pemberantasan penyakit menular, pendidikan kebersihan perorangan, dan pengembangaan rekayasa sosial ${ }^{9}$. Pengetahuan yang benar tentang pencegahan primer pada kasus COVID-19 perlu disosialisasikan kepada masyarakat. Saat ini, banyak sekali beredar informasi-informasi tidak benar (hoax) tentang cara-cara mencegah COVID-19 di msayarakat, yang justru membuat masyarakat bingung dan melakukan cara-cara yang kurang benar dan tidak rasional. Penulisan makalah ini bertujuan untuk mengkaji lebih jauh tentang pencegahan primer yang tepat dan rasional yang dapat dilakukan oleh masyarakat sebagai upaya pencegahan penularan kasus COVID-19.

\section{B. METODE PENELITIAN}

Metode yang digunakan dalam penelitian adalah studi kepustakaan. Studi kepustakaan adalah studi dengan objek penelitian berupa karya-karya kepustakaan, baik jurnal ilmiah, buku, artikel dalam media massa, maupun data-data statistika. Kepustakaan digunakan untuk menjawab permasalahan penelitian yang diajukan oleh penulis, dalam hal ini adalah bagaimana pencegahan primer yang tepat dan rasional dalam upaya pencegahan penularan kasus COVID-19. Penelitian ini merupakan penelitian deskriptif analisis yaitu memberikan edukasi dan pemahaman kepada pembaca. Jenis data yang digunakan dalam penelitian ini adalah data sekunder.

\section{HASIL TEMUAN DAN PEMBAHASAN}

Pencegahan primer dapat dilakukan dengan promosi kesehatan dan perlindungan diri. Promosi kesehatan dapat dilakukan dengan intervensi pada individu, misalnya makan makanan bergizi seimbang, berperilaku sehat, meningkatkan kualitas lingkungan untuk mencegah terjadinya penyakit. Perlindungan diri dilakukan melalui tindakan tertentu, misalnya imunisasi, proteksi pada bahan

8 Sontiva, N., Rahayuwati, L. dan Lukman, M, “Persepsi Siswi SMAN Tanjungsari terhadap Pencegahan Primer Penyakit Kanker Serviks," Jurnal Keperawatan'Aisyiyah, 6(1), Pp. 67-74 (2019)

9 Wijaksono, D, "Partisipasi Masyarakat dalam Pelaksanaan Program Gerakan Membangun Masyarakat Sehat (Gerbangmas)," (2017). 
industri berbahaya dan kebisingan, mencuci tangan dengan larutan antiseptik, mencuci tangan dengan sabun sebelum makan, dan lain-lain. ${ }^{10}$

Pencegahan primer dengan promosi kesehatan pada kasus COVID-19 dapat dilakukan dengan cara: (1) menyaring informasi dari media sosial, (2) menerapkan etika batuk, (3) konsumsi makanan bergizi, dan (4) olah raga. Pencegahan primer dengan perlindungan diri pada kasus COVID-19 dapat dilakukan dengan cara: (1) resignasi, (2) membersihkan tangan secara rutin, (3) menggunakan masker, (4) social distancing dan isolasi diri, dan (5) menghindari kontak tanpa pelindung dengan hewan liar.

\section{Menyaring informasi dari media sosial}

Informasi tentang COVID-19 mudah dijangkau oleh masyarakat melalui media sosial. Hasil data statistik yang dilakukan oleh Hootsuite We Are Soscial pada bulan Januari 2019 menunjukkan bahwa 56\% atau sekitar 150 juta penduduk Indonesia sebagai pengguna aktif media sosial. Platform media sosial yang paling banyak digunakan adalah Youtube sebesar 88\%, Whatsapp sebesar 83\%, Facebook sebesar $81 \%$, Instagram sebanyak $80 \%$ dan Twitter sebesar $52 \%{ }^{11}$. Hal ini mendukung informasi tentang COVID-19 mudah sampai ke masyarakat, namun juga dapat mempengaruhi pola pikir masyarakat. Banyak informasi yang menyebar, namun tidak semua informasi akurat. Berdasarkan hasil penelitian ditemuakan 50 berita palsu (hoax) tentang COVID-19 selama bulan Januari-Maret 2020 di Indonesia ${ }^{12}$. Kondisi ini membentuk kecemasan pada individu yang banyak menimbulkan respon negatif. Respon negatif yang muncul diantaranya gangguan psikosomatik, terjadi penimbunan alat kesehatan seperti masker dan hand sanitizer, dan lain-lain ${ }^{13}$.

Psikosomatik adalah gangguan fisik karena faktor kejiwaan dan akumalasi sosial emosi yang dapat menimbulkan guncangan pada individu ${ }^{14}$. Ketidakmampuan menghadapi sosial emosi dapat menyebabkan tubuh rentan mengalami gangguna fisik seperti nyeri perut, sesak nafas, sakit kepala, dan gangguna fisik lainnya ${ }^{15}$. Gangguan sesak nafas pada kasus psikosomatik mirip dengan gejala sesak pada COVID-19.

${ }^{10}$ Nurlita, Winda, Ayu, “Hubungan Dukungan Tenaga Kesehatan dengan Perilaku Pencegahan Hipertensi Lansia di Posyandu Nurus-Asyfa Rw 01 Kelurahan Tlogomulyo Semarang," Universitas Muhammadiyah Semarang, (2017).

11 Rohmah, Nurliya, Ni'matul, "Media Sosial sebagai Media Alternatif Manfaat dan Pemuas Kebutuhan Informasi Masa Pandemik Global Covid 19 (Kajian Analisis Teori Uses and Gratification)," AlI'lam: Jurnal Komunikasi Dan Penyiaran Islam 4, no. 1 (2020): 1-16.

12 Rahayu, R. N, “Analisis Berita Hoax Covid-19 di Media Sosial di Indonesia," Jurnal Ekonomi, Sosial \& Humaniora, 1(9), Pp. 60-73, (2020).

13 Winingsi, Yulpia, “Aktivitas Konseris dalam Membantu Pasien Rawat Inap Bangsal Bedah di RSUD M. Zein Painan," Jurnal Al-Irsyad: Jurnal Bimbingan Konseling Islam 1, no. 2 (2019): 187-200.

14 Umary, Mustafid, Amna, "Pengaruh Hipnoterapi pada Santriwati yang Menderita Psikosomatis di MA Muallimat NW Pancor," Psikoislamika: Jurnal Psikologi Dan Psikologi Islam 15, no. 1 (2018): 5-10.

15 Umary, Mustafid, Amna, "Pengaruh Hipnoterapi pada Santriwati yang Menderita Psikosomatis di MA Muallimat NW Pancor," Psikoislamika: Jurnal Psikologi Dan Psikologi Islam 15, no. 1 (2018): 5-10. 
Individu yang secara tiba-tiba mengalami sesak nafas belum tentu terkena COVID-19. Individu harus memastikan dengan melakukan pemeriksaan ke tenaga kesehatan agar tidak menimbulkan kecemasan yang berkepanjangan. Psikosomatik yang berkelanjutkan akan menurunkan daya tahan tubuh sehingga lebih memudahkan terjangkit COVID-19 ${ }^{16}$.

Upaya yang dapat dilakukan untuk mengatasi kondisi tersebut, maka individu harus selektif dalam memilih informasi. Tidak semua informasi di media sosial adalah benar. Bila mendapatkan informasi yang mengganggu, harus dilakukan konfirmasi dengan mencari informasi lainnya dari sumber yang terpercaya. ${ }^{17}$

\section{Menerapkan etika batuk}

COVID-19 menyebar melaui droplet (partikel) yang keluar dari mulut individu dengan positif COVID-19. ${ }^{18}$ Penerapan etika batuk perlu dilakukan untuk mencegah droplet yang keluar sehingga tidak menulari individu lain. Etika batuk dilakukan dengan menutup mulut dan hidung saat bersin dan batuk dengan menggunakan tisu atau lipatan tangan. Jangan lupa untuk segera mencuci tangan setelah bersin dan batuk. ${ }^{19}$

\section{Konsumsi makanan bergizi}

Dengan berkembangnya kasus COVID-19, berkembang pula isu tentang pilihan makanan yang dapat mencegah bahkan menyembuhkan COVID-19. Isu pertama tentang berupa tipe diet, seperti diet ketogenik dapat meningkatkan sistem imun dan mencegah penularan COVID-19. Kenyataannya, belum ada penelitian yang menunjukkan diet spesifik untuk mencegah penularan COVID-19.20

Isu kedua tentang konsumsi suplemen dan produk kesehatan, seperti vitamin C, vitamin D, zink, dan produk kesehatan lainnya dapat mencegah dan menyembuhkan COVID-19. Beberapa penelitian menunjukkan bahwa vitamin $C$ dan vitamin $\mathrm{D}$ dapat mencegah terjadinya infeksi saluran nafas, namun tidak spesifik mencegah penularan COVID-19. Penelitian tentang efek zink tidak menunjukkan adanya efek protektif ${ }^{21}$.

16 Yunus, Nur Rohim dan Rezki, Annissa, “Kebijakan Pemberlakuan Lock Down sebagai Antisipasi Penyebaran Corona Virus Covid-19," SALAM: Jurnal Sosial Dan Budaya Syar-I 7, no. 3 (2020).

17 Susilo, Adityo et al., "Coronavirus Disease 2019: Tinjauan Literatur Terkini," Jurnal Penyakit Dalam Indonesia 7, no. 1 (2020): 45-67.

18 Setiawan, Yusufa, Ibnu, Sina, "Penetapan Karantina Wilayah menurut Pandangan Legal Positivisme dalam Rangka Pencegahan dan Pemberantasan Pandemi Coronavirus Disease (Covid)-19," (2020).

19 El Ghoch, Marwan and Valerio, Alessandra, "Let Food be the Medicine, but Not for Coronavirus: Nutrition and Food Science, Telling Myths from Facts," Journal of Population Therapeutics and Clinical Pharmacology 27, no. 2 (2020): e1-4.

20 El Ghoch and Valerio, (2020).

21 El Ghoch and Valerio, (2020). 
Isu ketiga adalah "gargling" dengan air hangat, air cuka, dan air lemon dapat membersihkan tenggorokan sehingga mencegah penyebaran ke paru. Sampai saat ini, belum ada penelitian yang menunjukkan bahwa dengan "gargling" menggunakan bahan apapun dapat mencegah penularan COVID-19 ${ }^{22}$.

Nutrisi yang baik secara umum dapat meningkatkan daya tahan tubuh. Penerapan gaya hidup sehat berdasarkan pedoman diet yang diakui secara ilmiah, seperti "Healthy Eating Plate", yaitu mencukupi kebutuhan cairan, melakukan aktivitas fisik teratur, istirahat dan tidur yang cukup, serta mengurangi stres, adalah tindakan terbaik untuk memperkuat sistem kekebalan tubuh dan membantu untuk melawan kemungkinan berbagai infeksi ${ }^{23}$.

\section{Olahraga}

Masa pandemi COVID-19 cenderung membuat masyarakat memiliki gaya hidup kurang gerak. Hasil penelitian menunjukkan gaya hidup kurang gerak dapat menurunkan imunitas tubuh. Olahraga dianjurkan di masa social distancing dan isolasi diri untuk mencegah penularan COVID-19. Olahraga adalah aktifitas fisik yang terstruktur dan terencana dengan mengikuti aturan-aturan yang berlaku dengan tujuan untuk membentuk tubuh yang bugar ${ }^{24}$. Olahraga dapat menurunkan emosi negatif dengan produksi hormon endorfin yang meningkat. Beberapa penelitian menunjukkan olahraga dapat menjadi terapi pada penyakit kronis dengan meningkatkan kesehatan mental dan fisik. Rekomendasi olahraga yang dilakukan untuk mencegah penularan COVID-19 adalah olahraga intenitas sedang. Yang termasuk dalam olahraga intensitas sedang adalah aerobik, olahraga beban, olahraga keseimbangan, olahraga latihan mobilisasi dan koordinasi. Olahraga dilakukan minimal lima kali dalam seminggu dengan durasi waktu 150-300 menit per minggu ${ }^{25}$.

\section{Resignasi}

Resignasi sebagai salah satu gaya hidup yang tepat untuk mencegah COVID19. Resignasi adalah gaya hidup yang menggambarkan keseluruhan diri individu berserah diri dan lebih dekat pada Allah dalam berinteraksi dengan lingkungan sebagai hasil refleksi kondisi sosial. Resignasi memberikan rasa tenang dan cemas karena menjadikan Allah sebagai tempat bergantung, tempat berharap dan tempat meminta. Resignasi memberikan pemahaman bahwa pandemik COVID-19 merupakan

22 El Ghoch and Valerio, (2020).

23 Pavón, David Jiménez, Baeza, Ana Carbonell, and Lavie, Carl J, “Physical Exercise as Therapy to Fight against the Mental and Physical Consequences of COVID-19 Quarantine: Special Focus in Older People," Progress in Cardiovascular Diseases, (2020).

${ }^{24}$ Hadi, Faisal Kusuma, “Aktivitas Olahraga Bersepeda Masyarakat di Kabupaten Malang pada Masa Pandemi Covid-19," Sport Science And Education Journal 1, no. 2 (2020).

${ }^{25}$ Supriatna, Eman, “Wabah Corona Virus Disease (Covid 19) Dalam Pandangan Islam,” Salam: Jurnal Sosial Dan Budaya Syar-I 7, no. 6 (2020). 
ujian untuk meningkatkan ketaqwaan kepada Allah 26. Resignasi akan dapat membangkitkan motivasi yang kuat dalam menghadapi pandemik COVID-19 ${ }^{27}$.

Resignasi akan mendorong individu untuk berfikir dan memaknai sisi positif wabah COVID-19. Sisi positif yang didapat adalah seluruh manusia bersatu padu dan memliki rasa saling peduli, kebencian dan konflik menurun bahkan menghilang, dan memiliki waktu yang lebih banyak bersama kelurga. Resignasi sebagai mekanisme koping melalui masa-masa sulit ${ }^{28}$.

\section{Membersihkan tangan secara rutin}

Rekomendasi WHO dalam menghadapi wabah COVID-19 adalah cuci tangan secara rutin. Hal ini disebabkan karena COVID-19 dapat menular saat memegang mulut atau hidung tanpa mencuci tangan terlebih dahulu setelah menyentuh benda yang terkena cipratan air ludah penderita COVID-19 dan kontak jarak dekat dengan penderita COVID-19, seperti berjabat tangan ${ }^{29}$. Cuci tangan adalah proses mekanik untuk melepaskan kotoran yang menempel pada tangan dengan menggunakan deterjen yang mengadung antiseptik dan air mengalir, mulai ujung jari sampai siku dan lengan dengan cara tertentu sesuai kebutuhan ${ }^{30}$.

Cuci tangan tidak dianjurkan dengan menggunakan air saja. Air dikenal sebagai pelarut universal, namun tidak dapat menghilangkan COVID-19. Air tidak dapat melepaskan kotoran dan lemak pada saat cuci tangan. Anjuran cuci tangan yang benar adalah menggunakan sabun dan air atau handsanitizer ${ }^{31}$.

Hal-hal yang perlu diperhatikan dalam melakukan cuci tangan, yaitu (1) cuci tangan dengan sabun dan air bila tangan jelas terkontaminasi bahan yang mengandung protein atau lemak, (2) cuci tangan tangan dengan handsanitzer berbasis alkohol bila tangan tidak jelas terlihat kotor, (3) Sebelum melalui kegiatan, tangan harus dipastikan dalam kedaan kering ${ }^{32}$

Cuci tangan dengan sabun dapat menghilangkan virus COVID-19. Virus ini merupakan virus RNA dengan selubung lemak 2 lapis. Sabun mampu menghilangkan senyawa hidrofobik, seperti lemak dan minyak. Cuci tangan dengan air dan sabun

${ }^{26}$ Jarnawi Jarnawi, "Mengelola Cemas di Tengah Pandemik Corona," At-Taujih: Bimbingan dan Konseling Islam 3, no. 1 (2020): 60-73.

27 Buana, “Analisis Perilaku Masyarakat Indonesia Dalam Menghadapi Pandemi Virus Corona (Covid-19) Dan Kiat Menjaga Kesejahteraan Jiwa," Salam: Jurnal Sosial dan Budaya Syar-I 7, no. 3 (2020).

${ }^{28}$ Susilo et al., “Coronavirus Disease 2019: Tinjauan Literatur Terkini." Jurnal Penyakit Dalam Indonesia," 7(1), (2019), Pp. 45-67.

${ }^{29}$ Rohmah, "Media Sosial sebagai Media Alternatif Manfaat dan Pemuas Kebutuhan Informasi Masa Pandemik Global Covid 19 (Kajian Analisis Teori Uses And Gratification)." Al-I'lam: Jurnal Komunikasi Dan Penyiaran Islam 4, no. 1 (2020): 1-16

${ }^{30}$ Nakoe, Rivai, Lalu, Nur Ayini S, and Mohamad, Yesintha Amelia, "Perbedaan Efektivitas Hand-Sanitizer dengan Cuci Tangan Menggunakan Sabun sebagai Bentuk Pencegahan COVID-19," Jambura Journal of Health Sciences and Research 2, no. 2 (2020): 65-70.

${ }^{31}$ Susilo et al., "Coronavirus Disease 2019: Tinjauan Literatur Terkini," Jurnal Penyakit Dalam Indonesia," 7(1), (2019), Pp. 45-67

32 Nakoe, Lalu dan Mohamad, (2020) 
perlu dilakukan selama 45-60 detik. Cuci tangan harus dilakukan dengan benar melalui enam langkah. Enam langkah cuci tangan berupa meratakan sabun di telapak tangan, lalu menggosok punggung tangan dan sela jari, selanjutnya sela jari bagian depan, gerakan tangan mengunci, menggosok area antara telunjuk dan ibu jari, dan yang terakhir menggosok kuku jari ${ }^{33}$.

Rekomendasi handsanitizer adalah handsanitizer yang mengandung etanol 6271\%. Etanol dapat mengurangi efektivitas COVID-19. Cuci tangan dengan handsanitizer dilakukan selama 20-30 detik dengan tetap memperhatikan enam langkah cuci tangan 34. Setelah memakai handsanitizer 5-10 kali, dianjurkan tetap melakukan cuci tangan dengan sabun dan air untuk menghilangkan emolien yang menumpuk di tangan setelah beberapa kali menggunkan handsanitizer 35

Waktu-waktu yang diperlukan untuk melakukan cuci tangan adalah: (1) cuci tangan setelah tiba di tempat kerja, (2) cuci tangan sebelum dan sesuah berinteraksi dengan penderita COVID-19, (3) cuci tangan setelah memakai toilet umum, (4) cuci tangan sebelum menyentuh mata dan hidung, (5) cuci tangan sebelum dan sesudah makan ${ }^{36}$

\section{Menggunakan masker}

COVID-19 dapat menular dari manusia ke manusia melalui percikan ludah penderita saat bicara, bersin dan batuk ${ }^{37}$. Penggunaan masker menjadi metode efektif untuk mencegah penularan COVID-19. Masker harus dipakai oleh individu yang sehat maupun individu yang positif COVID-19. Penggunaan masker untuk individu yang sehat mencegah masuknya virus melaui hidung dan mulut. Selain itu, pemakaian masker juga dapat mengurangi kontak tangan dengan hidung dan mulut. Penggunaan masker untuk individu positif COVID-19 bertujuan untuk menghalangi penularan COVID-19 saat batuk atau bersin ${ }^{38}$. Pemakaian masker sebagai cara pencegahan yang paling sederhana dan murah, namun sangat efektif untuk mencegah penularan. Pemakaian masker terutama saat berada di fasilitas umum, seperti pusat pembelanjaan dan kendaraan umum ${ }^{39}$.

Ada banyak jenis masker yang beredar di masyarakat, mulai dari masker N95,

33 Sinaga, Munthe dan Bangun, "Sosialisasi Perilaku Cuci Tangan Pakai Sabun di Desa Sawo sebagai Bentuk Kepedulian terhadap Masyarakat di Tengah Mewabahnya Virus Covid-19." Jurnal Abdimas Mutiara 1, no. 2 (2020), pp 19-28.

34 Liu, Xiaopeng and Zhang, Sisen, "COVID-19: Face Masks and Human-to-human Transmission," Influenza and Other Respiratory Viruses, 2020.

35 Nakoe, Lalu, and Mohamad, (2020)"

36 Nakoe, Lalu, and Mohamad, (2020).

37 Rohmah, "Media Sosial Sebagai Media Alternatif Manfaat Dan Pemuas Kebutuhan Informasi Masa Pandemik Global Covid 19 (Kajian Analisis Teori Uses And Gratification)." Al-I'lam: Jurnal Komunikasi Dan Penyiaran Islam 4, no. 1 (2020): 1-16

${ }_{38}$ Trisha Greenhalgh et al., "Face Masks for the Public during the Covid-19 Crisis," BMJ 369 (2020).

39 Buana, “Analisis Perilaku Masyarakat Indonesia Dalam Menghadapi Pandemi Virus Corona (Covid-19) Dan Kiat Menjaga Kesejahteraan Jiwa." Salam: Jurnal Sosial dan Budaya Syar-I 7, no. 3 (2020). 
masker bedah, masker kain, sampai dengan masker scuba. Setiap masker meiliki efektifitas yang berbeda-beda. Masker N95 memiliki efektifitas 95-100\%, masker bedah memiliki efektifitas 80-90\%, masker kain 3 lapis memiliki efektifitas 50-70\%, dan masker scuba hanya memiliki efektifitas 0-5\%. Masker N95 dan masker bedah memiliki efektifitas yang paling tinggi. Masker ini banyak digunakan oleh tenaga kesehatan saat menangani pasien COVID-19. Selama pandemi, terjadi kekurangan masker N95 dan masker bedah. Hal ini mendorong penggunaan masker kain ${ }^{40}$.

Beberapa penelitian menunjukkan bahwa tingkat perlindungan masker kain tergantung dari ada tidaknya water resistant, jumlah benang yang banyak, dan tenunan kain yang lebih halus. Penggunaan masker kain yang dianjurkan adalah masker kain 3 lapis. Penggunaan masker scuba tidak dianjurkan karena memiliki efektifitas yang rendah ${ }^{41}$. Terkait dengan penggunana masker kain ini, WHO menyarankan bahwa penggunaan masker kain menjadi pertimbangan sebagai pengendalian penularan di masayarakat, bukan sebagai pencegahan. Karena masker kain memiliki persyaratan standar filtrasi, kemudahan bernafas, dan efektifiatas kerjanya. Penggunaan masker kain harus diimbangi dengan perilaku cuci tangan sesering mungkin dan melakukan jaga jarak fisik (social distancing) ${ }^{42}$.

\section{Social Distancing dan isolasi diri}

Konsep social distancing merupakan konsep menjaga jarak aman dengan manusia lain minimal 2 meter untuk mengurangi bahkan memutus mata rantai penularan COVID-19 ${ }^{43}$. Tujuan utama dari social distancing adalah mengurangi kemungkinan kontak fisik antara orang yang terinfeksi dengan orang yang tidak terinfeksi sehingga meminimalkan penularan penyakit. Social Distancing dapat dipraktekkan dengan tidak meninggalkan rumah kecuali ada keperluan yang mendesak seperti membeli obat, membeli bahan makanan, dan kegiatan lainnya. Social Distancing juga dapat dilakukan tidak berjabat tangan, cukup melambaikan tangan atau memberi salam dengan mengangkat kedua tangan bila bertemu dengan orang lain. Contoh yang lain adalah bekerja dari rumah, sekolah dari rumah, tidak melakukan kegiatan yang mengundang banyak orang, dan tidak mengunjungi orang sakit ${ }^{44}$.

Konsep isolasi diri adalah memisahkan diri sehingga tidak memiliki relasi dengan individu lain. Virus korona dapat menular dari manusia ke manusia. Individu yang sehat dapat menularkan ataupun tertular oleh individu lain. COVID-19 dapat

40 Dwirusman, Cindy Gustavia, "The Role and Effectivity of Face Mask in Preventing Transmission of Coronavirus Disease 2019 (COVID-19)," Jurnal Medika Hutama 2, no. 1 (2020): 412-20.

${ }^{41}$ Dwirusman, (2020).

${ }^{42}$ Eikenberry, Steffen E et al., "To Mask or Not to Mask: Modeling the Potential for Face Mask Use by the General Public to Curtail the COVID-19 Pandemic," Infectious Disease Modelling, (2020).

43 Setiawan, Y. I. S, "Penetapan Karantina Wilayah menurut Pandangan Legal Positivisme dalam Rangka Pencegahan dan Pemberantasan Pandemi Coronavirus Disease (Covid)-19," OSF Preprints, (2020).

${ }^{44}$ Kresna, Arief and Ahyar, Juni, "Pengaruh Physical Distancing dan Social Distancing terhadap Kesehatan dalam Pendekatan Linguistik," Jurnal Syntax Transformation 1, no. 4 (2020): 14-19. 
ditularkan dari individu positif COVID-19 tanpa gejala atau dikenal dengan Orang Tanpa Gejala (OTG) ${ }^{45}$. OTG pada umumnya memiliki riwayat kontak erat dengan pasien COVID-19. Seseorang yang memliki riwayat kontak erat harus melakukan isolasi mandiri. Yang termasuk dalam kontak erat adalah :

1. Petugas kesehatan yang memeriksa, merawat, dan membersihkan ruangan merawat pasien positif COVID-19.

2. Individu yang tinggal satu rumah dengan individu positif COVID-19.

3. Tamu yang berada satu ruangan dengan individu positif COVID-19.

4. Bekerja bersama dalam jarak dekat atau di dalam satu ruangan sama dengan individu positif COVID-19.

5. Bepergian bersama dengan segala jenis kendaraan dengan individu positif COVID-19.46

COVID-19 menyebar secara contagious. Istilah contagious mengacu pada infeksi yang menyebar secara cepat dalam suatu jaringan. Dalam penyebaran secara contagious, elemen yang saling terhubung dalam suatu jaringan dapat saling menularkan infeksi. Istilah contagious tidak terbatas pada penyakit, tetapi secara metafora dapat menyebar dari sati individu ke individu lainnya. Hasil analisis jaringan menunjukkan konsep Social distancing dan isolasi diri dapat menurunkan kepadatan jaringan dan tidak terpusat di tengah jaringan sehingga dapat mengurangi dan menghilangkan penularan COVID-19 ${ }^{47}$.

\section{Menghindari kontak tanpa pelindung dengan hewan liar}

Asal mula COVID-19 ditemukan di kota Wuhan. Individu dengan positif COVID-19 di kota Wuhan banyak dilaporkan dari individu yang kontak dengan pasar hewan dan individu yang konsumsi makanan laut. Di pasar hewan tersebut menjual berbagai macam hewan liar, seperti ular, kelelawar, dan ayam. Diduga COVID-19 berasal dari kelelawar dan ular. Virus COVID-19 dapat menular dari hewan ke manusia melalui kontak langsung dengan hewan. ${ }^{48}$.

Salah satu cara untuk menghindari penularan COVID-19 adalah tidak kontak dengan hewan liar. Bila pun karena faktor pekerjaan atau keterpaksaan kontak denga hewan liar, maka harus menggunakan pelindung dan segera ganti baju dan cuci tangan atau mandi setelah selesai kontak.

\footnotetext{
${ }^{45}$ Mona, Nailul, “Konsep Isolasi dalam Jaringan Sosial untuk Meminimalisasi Efek Contagious (Kasus Penyebaran Virus Corona Di Indonesia)," Jurnal Sosial Humaniora Terapan 2, no. 2 (2020).

${ }^{46}$ Fatimah, Inge Rika, “Dampak Meningkatnya Harga Masker di Tengah Mewabahnya Covid-19 di Kalangan Masyarakat ditinjau dari Sudut Pandang Tindakan Manusia," Osf Preprints, (2020).

${ }^{47}$ Rohmah, "Media Sosial Sebagai Media Alternatif Manfaat Dan Pemuas Kebutuhan Informasi Masa Pandemik Global Covid 19 (Kajian Analisis Teori Uses And Gratification), " Al-I'lam: Jurnal Komunikasi Dan Penyiaran Islam 4, no. 1 (2020): 1-16.

${ }^{48}$ Dwirusman, "The Role and Effectivity of Face Mask in Preventing Transmission of Coronavirus Disease 2019 (COVID-19)," Jurnal Medika Hutama 2, no. 1 (2020): 412-20.
} 


\section{KESIMPULAN}

Pencegahan primer pada COVID-19 dapat dilakukan melalui promosi kesehatan dan perlindungan khusus. Pencegahan primer dengan promosi kesehatan dilakukan dengan selektif memilih informasi dari media sosial, menerapkan etika batuk, konsumsi makanan bergizi, dan olahraga. Pencegahan primer dengan perlindungan khusus dilakukan dengan resignasi. membersihkan tangan secara rutin, menggunakan masker, social distancing dan isolasi diri, serta menghindari kontak tanpa pelindung dengan hewan liar.

Saran yang dapat diberikan adalah menghimbau kepada masyarakat untuk melakukan pencegahan primer yang tepat pada kasus COVID-19. Selain itu, perlu dilakukan kajian yang berbeda tentang pencegahan sekunder dan pencegah tersier sebagai upaya pencegahan penularan kasus COVID-19 sebagai pegangan yang benar bagi masyarakat.

\section{REFERENSI:}

Buana, Dana Riksa. "Analisis Perilaku Masyarakat Indonesia Dalam Menghadapi Pandemi Virus Corona (Covid-19) Dan Kiat Menjaga Kesejahteraan Jiwa." Salam: Jurnal Sosial Dan Budaya Syar-I 7, No. 3 (2020).

Dwirusman, Cindy Gustavia. “The Role And Effectivity Of Face Mask In Preventing Transmission Of Coronavirus Disease 2019 (Covid-19)." Jurnal Medika Hutama 2, No. 1 (2020): 412-20.

Eikenberry, Steffen E, Marina Mancuso, Enahoro Iboi, Tin Phan, Keenan Eikenberry, Yang Kuang, Eric Kostelich, And Abba B Gumel. “To Mask Or Not To Mask: Modeling The Potential For Face Mask Use By The General Public To Curtail The Covid-19 Pandemic." Infectious Disease Modelling, (2020).

Fajar, Muhammad. "Estimation Of Covid-19 Reproductive Number Case Of Indonesia," (2020).

Fatimah, Inge Rika. “Dampak Meningkatnya Harga Masker Di Tengah Mewabahnya Covid-19 Di Kalangan Masyarakat Ditinjau Dari Sudut Pandang Tindakan Manusia," (2020).

Ghoch, Marwan El, And Alessandra Valerio. "Let Food Be The Medicine, But Not For Coronavirus: Nutrition And Food Science, Telling Myths From Facts." Journal Of Population Therapeutics And Clinical Pharmacology 27, No. 2 (2020): E1-4.

Greenhalgh, Trisha, Manuel B Schmid, Thomas Czypionka, Dirk Bassler, And Laurence Gruer. "Face Masks For The Public During The Covid-19 Crisis." Bmj 369 (2020).

Hadi, Faisal Kusuma. "Aktivitas Olahraga Bersepeda Masyarakat Di Kabupaten Malang Pada Masa Pandemi Covid-19." Sport Science And Education Journal 1, No. 2 (2020).

Jarnawi, Jarnawi. "Mengelola Cemas Di Tengah Pandemik Corona." At-Taujih: 
Bimbingan Dan Konseling Islam 3, No. 1 (2020): 60-73.

Jiménez-Pavón, David, Ana Carbonell-Baeza, And Carl J Lavie. “Physical Exercise As Therapy To Fight Against The Mental And Physical Consequences Of Covid-19 Quarantine: Special Focus In Older People." Progress In Cardiovascular Diseases, (2020).

Kompas.Com. “Update 20 April: Sebaran 185 Kasus Baru Pasien Covid-19 Di 13 Provinsi," 2020. Https://Nasional.Kompas.Com.

Kresna, Arief, And Juni Ahyar. "Pengaruh Physical Distancing Dan Social Distancing Terhadap Kesehatan Dalam Pendekatan Linguistik." Jurnal Syntax Transformation 1, No. 4 (2020): 14-19.

Ladimo, Mutiara Patricia, And Irwan Irwan. "Mers-Cov (Middle East Respiratory Syndrome-Corona Virus) Menggegerkan Dunia Timur." Journal Health $\mathcal{E}$ Science: Gorontalo Journal Health And Science Community 4, No. 1 (2020): 18-28.

Liu, Xiaopeng, And Sisen Zhang. "Covid-19: Face Masks And Human-To-Human Transmission." Influenza And Other Respiratory Viruses, (2020).

Mona, Nailul. “Konsep Isolasi Dalam Jaringan Sosial Untuk Meminimalisasi Efek Contagious (Kasus Penyebaran Virus Corona Di Indonesia)." Jurnal Sosial Humaniora Terapan 2, No. 2 (2020).

Nakoe, Rivai, Nur Ayini S Lalu, And Yesintha Amelia Mohamad. "Perbedaan Efektivitas Hand-Sanitizer Dengan Cuci Tangan Menggunakan Sabun Sebagai Bentuk Pencegahan Covid-19." Jambura Journal Of Health Sciences And Research 2, No. 2 (2020): 65-70.

Nurlita, Winda Ayu. "Hubungan Dukungan Tenaga Kesehatan Dengan Perilaku Pencegahan Hipertensi Lansia Di Posyandu Nurus-Asyfa Rw 01 Kelurahan Tlogomulyo Semarang." Universitas Muhammadiyah Semarang, (2017).

Rohmah, Nurliya Ni'matul. “Media Sosial Sebagai Media Alternatif Manfaat Dan Pemuas Kebutuhan Informasi Masa Pandemik Global Covid 19 (Kajian Analisis Teori Uses And Gratification)." Al-I'lam: Jurnal Komunikasi Dan Penyiaran Islam 4, No. 1 (2020): 1-16.

Setiawan, Yusufa Ibnu Sina. "Penetapan Karantina Wilayah Menurut Pandangan Legal Positivisme Dalam Rangka Pencegahan Dan Pemberantasan Pandemi Coronavirus Disease (Covid)-19," (2020).

Sinaga, Lia Rosa Veronika, Seri Asnawati Munthe, And Henny Arwina Bangun. "Sosialisasi Perilaku Cuci Tangan Pakai Sabun Di Desa Sawo Sebagai-Bentuk Kepedulian Terhadap Masyarakat Ditengah Mewabahnya Virus Covid-19." Jurnal Abdimas Mutiara 1, No. 2 (2020): 19-28.

Sontiva, Nessa, Laili Rahayuwati, And Mamat Lukman. "Persepsi Siswi Sman Tanjungsari Terhadap Pencegahan Primer Penyakit Kanker Serviks." Jurnal Keperawatan'aisyiyah 6, No. 1 (2019): 67-74.

Supriatna, Eman. “Wabah Corona Virus Disease (Covid 19) Dalam Pandangan Islam.” 
Salam: Jurnal Sosial Dan Budaya Syar-I 7, No. 6, (2020).

Susilo, Adityo, Cleopas Martin Rumende, Ceva Wicaksono Pitoyo, Widayat Djoko Santoso, Mira Yulianti, Herikurniawan Herikurniawan, Robert Sinto, Gurmeet Singh, Leonard Nainggolan, And Erni Juwita Nelwan. "Coronavirus Disease 2019: Tinjauan Literatur Terkini." Jurnal Penyakit Dalam Indonesia 7, No. 1 (2020): $45-67$.

Telaumbanua, Dalinama. “Urgensi Pembentukan Aturan Terkait Pencegahan Covid-19 Di Indonesia." Qalamuna: Jurnal Pendidikan, Sosial, Dan Agama 12, No. 1 (2020): 59-70.

Umary, Mustafid Amna. "Pengaruh Hipnoterapi Pada Santriwati Yang Menderita Psikosomatis Di Ma Muallimat Nw Pancor." Psikoislamika: Jurnal Psikologi Dan Psikologi Islam 15, No. 1 (2018): 5-10.

Wijaksono, Dwi. "Partisipasi Masyarakat Dalam Pelaksanaan Program Gerakan Membangun Masyarakat Sehat (Gerbangmas)," (2017).

Winingsi, Yulpia. “Aktivitas Konseris Dalam Membantu Pasien Rawat Inap Bangsal Bedah Di Rsud M. Zein Painan.” Jurnal Al-Irsyad: Jurnal Bimbingan Konseling Islam 1, No. 2 (2019): 187-200.

Yunus, Nur Rohim, And Annissa Rezki. “Kebijakan Pemberlakuan Lock Down Sebagai Antisipasi Penyebaran Corona Virus Covid-19." Salam: Jurnal Sosial Dan Budaya Syar-I 7, No. 3 (2020).

Zulva, Tarisa Novita Indana. “Covid-19 Dan Kecenderungan Psikosomatis,” (2020). 
Nikma Fitriasari

1246 - Fakultas Syariah dan Hukum UIN Syarif Hidayatullah Jakarta 